\title{
Effects of Increased Commercial Navigation Traffic on Freshwater Mussels in the Upper Mississippi River: 1994 Studies
}

by Andrew C. Miller, Barry S. Payne

U.S. Army Corps of Engineers Waterways Experiment Station 3909 Halls Ferry Road

Vicksburg, MS 39180-6199

Final report

Approved for public release; distribution is unlimited

Prepared for U.S. Army Engineer District, St. Louis

St. Louis, MO 63103-2833 